\title{
Assessing the Competitive Performance of National and International Higher Education Institutions
}

\author{
Vladislav Spitsin \\ Department of Management \\ Tomsk Polytechnic University \\ Tomsk, Russia \\ spitsin_vv@mail.ru \\ Inna Krakovetskaya \\ Tomsk Polytechnic University \\ Tomsk, Russia
}

\author{
Ekaterina Vorobyeva \\ National Research Nuclear University MEPhI \\ Moscow, Russia
}

Georgiy Osokin

Tomsk Polytechnic University

Tomsk, Russia

\begin{abstract}
The paper analyzes the available approaches to the evaluation of international competitiveness of higher education institutions based on contemporary world rankings. We discuss university performance indices and outcome indicators such as ARWU (Academic Ranking of World Universities), THE (Times Higher Education World University Ranking), and QS (QS World University Ranking) as well as a number of alternative techniques. Specific features and limitations of the world university ranking systems are investigated and so are the potential reasons for high positions of the leading national universities. The investigations of the Russian and Western researchers and experts are shown to support the fact that the national higher education institutions demonstrate world-level competences in certain fields of science. The data reported contribute to the development of the competitiveness theory and could be used by the top management of universities in designing and correcting their development strategies.
\end{abstract}

Keywords-higher education; research institutions; education policy; world rankings; competitiveness

\section{INTRODUCTION}

The current stage of world economic development is characterized by such key features as high instability of the environment, ever increasing competition and globalization, as well as new objectives and goals put forward before universities by the government and society. Under the conditions of tough competition, there is more emphasis on the image of today's universities, specifically: reputation of a university and qualification of its staff and alumni. On the one hand, there is a challenge to meet the expectations of more educated and demanding consumers to receive high-quality education; on the other hand, universities have to be financially stable and remain market players. Entering the world educational landscape has aggravated certain problems for the Russian universities.

The essential features of competition among universities and their alumni have been reported in both international and Russian literature. Reference [1], for instance, points out that competitiveness of a university alumnus is an 'integral index including his/her capacity to withstand competition in the labor market, to occupy his/her working place in accordance with the degree-qualified profile and effectively fulfill the respective job functions'.

It is currently a common practice to evaluate the competiveness of university alumni through that of the respective university with a certain status in the world and domestic ranking systems. The range of problems existing in the university ranking systems in Russia and worldwide has been investigated in [2] and a number of other works.

At present, competitiveness rankings have become a global phenomenon. On the one hand, their aim is to satisfy the demand of consumers (university applicants, employers, universities, etc.) in acquiring the information about the university of interest, helping them to distinguish between the multitudes of universities in the market and to make a correct choice. On the other hand, they stimulate and foster competition among the educational establishments, identifying the strongest and most successful of them. The rankings build up a certain rationale for distribution of funds and, given a correct interpretation, they contribute to both the determination of world-class universities and the notion of 'university quality'.

Many of the experts and researchers strongly criticize these rankings for the biased estimation of university performance. This is especially relevant in application of 'weighing coefficients' determining the significance of indicators and the degree of authenticity of the data used in calculating the rankings [3]. This criticism also involves the use of indicators estimating the value and impact of scientific research. A single aggregated index cannot provide a uniformly weighted estimate of the entire range of university performance indicators (teaching quality of a university, its role in the social and economic development of the country, etc.). According to [4], the available rankings are targeted at fundamental research but are not well balanced in terms of an equal access of applicants with different languages and cultural backgrounds to higher education.

An ever increasing number of researchers note that the available rankings are incapable of making a comprehensive account of the individual features of modern universities; frequently their methodologies rely on one-dimensional 
approaches, each having a single indicator only and a set of the respective weighing coefficients. Undoubtedly, this approach offers priorities to the research-oriented universities but cannot meet the demand of all consumers in more comprehensive information on the performance and activities of the world universities.

There is a variety of ranking groups, such as integral, multifactor, scientometrical, web rankings, etc. They total to more than 20 international rankings, among which the most popular and competent international approaches to evaluating the performance of higher education are: ARWU (Academic Ranking of World Universities), THE (Times Higher Education World University Ranking), and QS (QS World University Ranking).

In this work, we attempt to analyze the available tools and algorithms of the global international rankings and to identify competitive positions of the top Russian universities under conditions of their integration into the global education landscape.

\section{RANKINGS OF WORLD UNIVERSITY} COMPETITIVENESS: PROBLEMS, TRENDS, PROSPECTS

The history of university ranking dates back to 1983, when the journal US News \& World Report issued the first ranking report in the world, which outlined the evolving processes of globalization of higher education. At the turn of the XXI century, there appeared a whole ranking industry, where belonged not only mass media companies but also specialized research laboratories [5].

\section{A. Academic Ranking of World Universities, or Shanghai Ranking (ARWU)}

It was originally compiled and issued by Shanghai Jiaotong University in 2003. The number of evaluated universities was 1200, with top 500 world universities published in the ranking tables. Six key indicators of university performance are now taken into account when compiling the ranking tables: 1 . Alumni. Total number of alumni as Nobel laureates \& Fields Medalists; 2. Award. Total number of staff as Nobel Laureates \& Fields Medalists; 3. HiCi. Highly cited researchers in 21 broad subject categories; 4. N\&S. Papers published in Nature and Science within recent five years ('paper' and 'conference proceedings' category only); 5. PUB. Faculty publications in the journals indexed in Science Citation Index-expanded (indexed in the ISI Web of Knowledge database); 6. PCP. Number of fulltime faculty and research staff.

The Shanghai ranking represents a list of the leading world universities compiled in the following manner: the list begins with 100 universities each having its rank; the remaining 400 are grouped in the alphabetical order, 50 and 100 per group (101-150, 151-200, 201-300, etc.).

Since ARWU's first issue and up to now, the US and Great Britain universities have invariably occupied the top places (Harvard - 1st place, Cambridge - 5th place).

In 2015, there were 42 countries featured in Top-500 world ranking universities. By the number of universities included into Top-500, the leading places have permanently belonged to the USA (146 universities), China (44 universities), Germany (39 universities) and Great Britain (37 universities). These are followed by France (20 universities) and Japan (18 universities). The representation of Chinese universities has been essentially extended within recent years from 16 in 2004 to 44 universities in 2015.

A different university ranking pattern is observed in Top100. The USA universities occupy $50 \%$ of all leading positions (Fig. 2).

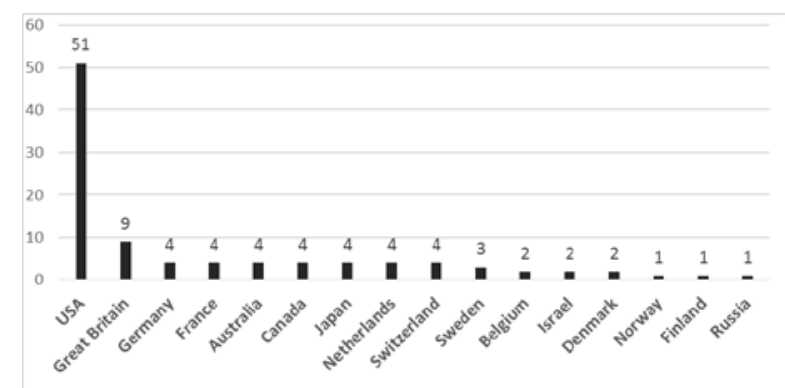

Fig. 1. Distribution of world universities by country according to Top-100 Shanghai ranking 2015 (compiled by the authors using data from: http://www.shanghairanking.com)

Only one Russian university was included into the Top100 world university ranking list - the Lomonosov Moscow State University, MSU. Its positions have not undergone serious changes since 2004. One more Russian university: Saint Petersburg State University, SPbSU, is on Top-300 of the world university ranking list.

In this study, we performed a comparative analysis of the indicators of Russian higher education institutions (MSU and SPbSU) with those in the ARWU Top-10 ranking in order to determine the strengths and weaknesses of Russian higher education.

The weakest indicator for the two Russian universities present in the ranking table is the highly cited researchers in 21 broad subject categories (HiCi). This outcome could be attributed to the absence of an interest in the Russian research on the part of the world scientific community, poor integration of the Russian science into the world scientific landscape, and a tendency of the US scientists to cite only American colleagues - their compatriots. MSU and SPbSU demonstrate rather low rankings in $\mathrm{N} \& \mathrm{~S}$, Papers published in Nature and Science.

Nevertheless, there are indicators where MSU might compete with the top ten universities in the world rankings. These are such indicators as the total number of alumni as Nobel laureates \& Fields Medalists (Alumni) and Faculty publications in the journals indexed in Science Citation Indexexpanded SCIE/SSCI (PUB).

\section{B. The Times Higher Education World University Ranking (THE)}

This is a well-known and competent ranking list annually published in Britain by The Times Higher Education Supplement, which was first presented to the public in 2004. 
Since 2005, the rankings have been compiled together with the QS Company (Quacquarelli Symonds), involved in collecting all the necessary information from the universities.

In 2010, The Times broke its contract with QS and signed a cooperation agreement with Thomson Reuters, the leading company in the field of data analysis and processing, which is the owner of a large scientometrical system, Web of Science.

In September 2010, The Times Higher Education journal and the Thomson Reuters Company presented to the public the outcome of the Times new global ranking table including Top-200 world universities. The key novelty of the new version of THE was a greater number of university performance indicators (13 instead of 6 in the previous ranking versions).

The developers of the ranking system laid emphasis on the three major roles of a university - education, research and innovation. Less attention was given to the estimates relying on the surveys of the academic community, thus decreasing the weight of these indicators. This made the ranking more impartial and objective, and an extended number of indicators provided a more accurate pattern of the world higher education.

1. Teaching (30\%). Ranking of teaching covers the following performance indicators: 1) Teaching reputation (from academic community surveys) - 15\%; 2) Staff-to-student ratio - 4.5\%; 3) Doctorate-to-Bachelor's ratio - 2.25\%; 4) Faculty with scientific degrees - 6\%; 5) Institutional income-to-number of staff, normalized with respect to the purchasing power of the currency $-2.25 \%$.

2. Research (30\%). Research efficiency, including: 1) University research (from reputation surveys) - 18\%; 2) Research income - 6\%; 3) Research productivity (only papers by the faculty published in the Elsevier's Scopusindexed databases) $-6 \%$.

3. Citations (30\%). (Research influence). Total number of citations normalized with respect to the subject area within 2010-2014 - 30\%

4. International outlook (7.5\%). Internationalization includes: 1) International-to-domestic student ratio - 2.5\%; 2) International student ratio - 2.5\%; 3) International collaboration normalized over subject area in 2010/14 $2.5 \%$.

5. Industry income (2.5\%). (Knowledge transfer). Industry income per number of faculty, normalized over the purchasing power of the currency $-2.5 \%$.

An analysis of the geographic distribution of world universities in the 2011-2015 Times rankings has shown that the USA and Great Britain lead the rankings.

The number of universities included into the rankings is increasing every year and so is the representation of Russian higher educational institutions. In 2011, none of Russian universities was included into the new ranking tables, while in 2015 thirteen universities appeared on the list. This is 7 times as many as in 2014, which indicates the fastest increase among 40 countries evaluated in the rankings.
The highest position among Russian universities in the world ranking list (161-st place) is occupied by MSU; it has moved 35 positions up.

Today the 'palm of victory' in higher education, according to THE rankings, belongs to the California Institute of Technology (USA), Oxford University (Great Britain) is the second, and Stanford University (USA) is in the third place.

Currently, about 2000 universities are somehow involved in compilation of QS World University Rankings, 700 of which are evaluated in terms of their performance. There are six principal indicators used in QS rankings.

1. Academic reputation (40\%). Academic reputation (academic surveys). QS Global Academic Surveys are held among the professors and administrators with on average 19.6 years of research and management experience. Here belong the leading world scientists and rectors of more than 500 universities. The respondent can name up to 30 universities, without mentioning his/her own affiliation.

2. Employer reputation (10\%). Employer reputation (academic surveys). Several thousand companies from more than 90 countries of the world take part in the QS Global Employer Survey. The employers are asked to name the best universities training highly qualified specialists.

3. Student-to-faculty ratio (20\%). It is the ratio between the number of teachers and undergraduates.

4. Citations per faculty (20\%). Index of citations of the papers published by the faculty with respect to the number of faculty. The source used by QS is SCOPUS, a bolometric database. The publications and citations are estimated within an equal period of 5 years.

5. International faculty ratio (5\%). Fraction of international teachers with respect to total teaching staff (based on fulltime equivalent). An international teacher is the one whose citizenship is different from the country the university is based in.

6. International student ratio (5\%). Fraction of international students with respect to total number of undergraduates (full-time training cycle curricula). The number of international students (residents of a country different from the one the university is based in), is divided by the total number of students.

It is evident that a distinguishing feature of QS World University Rankings is a large weight attributed to the 'academic reputation' indicator, which introduces a certain degree of subjectivism into the university evaluation and casts doubt on the reliability of the data used, since the experts do not always have all comprehensive university performance data at their disposal. Russian experts [6] also support this opinion; they believe that QS rankings are primarily targeted at giving advantage to 'English-speaking' universities, since they so strongly rely on publications in the English language and opinions of the English-speaking experts. 
In 2015, more than 800 universities from 70 countries of the world were involved in QS rankings. Similar to the previous two ranking events, the USA and Great Britain are the leaders in the number of universities, both in Top-100 and Top-800 tables (Fig. 2).

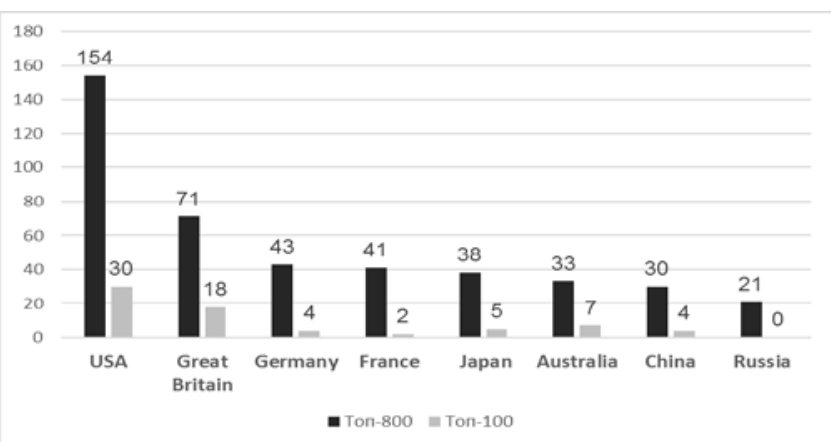

Fig. 2. Geographic distribution of world universities included into TOP- 800 and TOP-100 according to QS world university rankings 2015-2016 (compiled by the authors using data from: http://www.topuniversities.com)

The top three leaders are as follows: the first place Massachusetts Institute of Technology (USA), the second place - Harvard University (USA), and the third place Cambridge University (Great Britain).

Top-5 universities of Russia, in that order, occupy the following positions in the world university rankings 2015/16: Lomonosov Moscow State University - 108th place (2014 114 place, 2013 - 120 place), Saint Petersburg State University - 256th place (2014 - 233, 2013 - 240), Novosibirsk State University - 317th place (2014 - 328, 2013 - 352), Bauman Moscow State Technical University 338th place (2014 - 322, 2013 - 334), Moscow State Institute of International Relations - 397th place (2014 - 399, 2013 - 386).

The universities of USA and Great Britain undoubtedly have been taking the lead for many years both in the number of their universities present in the global rankings and in the top positions. The universities of these countries have built huge resources (material and intellectual), they carry out largescale fundamental research and are, in fact, the top-of-therange in the world education landscape, with the higher education institutions of developed and developing countries willing to pattern themselves on these universities, often losing their own individual features.

\section{SUMMARY}

The outcomes of global rankings vividly demonstrate that investments into higher education result in the foundation of world-level universities, e.g., in Canada, China, and South Korea. For instance, the budgets of Peking and Tsinghua Universities in 2014 rocketed above 6 billion USD. According to the data reported in [7] and [8], these countries make considerable investments into education, improving their global rankings with each coming year.

According to the RF Minister of science and education, Dmitry Livanov, 'Getting into the rankings is not a goal in itself. Our objective is to improve the performance of the leading universities and to increase their competiveness'. Indeed, Russian universities demonstrate positive dynamics in the key indicators of the global rankings, yet we believe this is insufficient for them to enter Top 100 in the near future. Yaroslav Kuzminov, Rector of National Research University Higher School of Economics, believes that 'solving this task might take 10 to 15 years because of the methodology used in calculating the global rankings' [9].

These downbeat forecasts of the experts push the government of Russia to amending Russian president's decree, in particular by steering Russian universities towards the industrial rankings, where universities are evaluated in terms of their industrial profile, taking into account special features of their operations. It is worth mentioning that in the industrial rankings Russian universities demonstrate most notable results, which proves that Russian higher education has world competences and proficiencies of the world level, particularly in specific branches of science.

Among the future research challenges of the authors of this study are: to analyze the industrial rankings, to extend the representative sampling, and to search for most appropriate tools and algorithms for evaluating competitiveness of the international and Russian universities allowing the objective outcome indicators and special features of operation and performance to be taken into account.

\section{REFERENCES}

[1] Golovanova L.A., Bondarenko N.A. and Syupova M.S. (2015), Systemic evaluation of university alumni competitiveness [in Russian], Pacific National University Bulletin, No. 1(136), 116-122.

[2] Kharchenko E.V, Spitsyn E.V., Voitash L.A. (2013), Growth imperatives of Russian university competitiveness through the prism of world ranking systems [in Russian], Zh. Sots.-Ekon. Yavl. Protsessy., No.6, 148-153.

[3] Chistyakova N.O., Krakovetskaya I.V., Vorobieva E.S. (2013) Evaluation of the University Potential as an Element of Innovative Environment of a Region [in Russian], Kreativn. Ekonom., 9 (81), 105-113.

[4] Karelina I.G. (2005) Ranking of Universities and Academic Programs as a Method for Evaluating Higher Education Quality in Different Countries: an Analytical Review [in Russian], VGU Bulletin, Series: Problems of Higher Education, 1, 101-108.

[5] Sadovnichiy V. (2016) Rankings - How to Estimate the Education Quality, Electronic Resource, Access at: http://expert.ru/expert/2008/04/kachestvo_obrazovanie/

[6] Kotliar P., Gorodetsky N. (2015) Russian Universities Moving towards a Hundred [in Russian], Electronic Resource, Access at: http://www.gazeta.ru/science/2015/09/15_a_7757021.shtml

[7] Chan Sheng-Ju. (2012) Enhancing Global Competitiveness: University Ranking Movement in Asia. Electronic Resource. Access at: http://www.ireg-observatory.org/ireg-6/presentation/shengju.pdf

[8] Koh Kyeong-mo. (2012) Enhancing University Competitiveness through Educational Facilities. Electronic Resource. Access at: http://www.cele2012korea.com/images/pdf/Session0-2_e.pdf

[9] Chernykh A. (2015) Universities Would be Classified by Industry Branches [in Russian]. Electronic Resource. Access at: http://www.kommersant.ru/doc/2836046 